\title{
ANALISIS SENTIMEN TOPIK VIRAL DESA PENARI PADA MEDIA SOSIAL TWITTER DENGAN METODE LEXICON BASED
}

\author{
Rifiana Arief $^{1}$, Karel Imanuel ${ }^{2}$ \\ Universitas Gunadarma ${ }^{1,2}$ \\ Jalan Margonda Raya No 100 Depok Jawa Barat 16424 \\ Sur-el : rifiana@staff.gunadarma.ac.id ${ }^{1}$, karel4404@gmail.com²
}

\begin{abstract}
The horror story of Dancer Village in Indonesia is a viral topic that has become a talk of citizens on Twitter social media. Various responses and public opinions emerged related to the truth of the story of supernatural experiences of students during a Real Work Lecture in an East Java region of Indonesia. This study conducted a sentiment analysis of community comments on Twitter social media on the viral topic using the Lexicon Based method. Sentiment classification is divided into 3 classes namely positive, negative and neutral. The research phase consists of data collection, pre-processing, processing (sentiment analysis) and visualization. Data collection uses Twitter Search API with 1000 Penari Desa keywords in Indonesian. The lexicon assessment results from 1000 tweets data obtained 33 positive, 767 neutral and 200 negative. The percentage of tweets containing positive comments by $3.3 \%$, neutral $76.7 \%$ and negative by $20 \%$.
\end{abstract}

Keywords: Dancer Village, Sentiment Analysis, Lexicon Based, Twitter, WorldCloud

\begin{abstract}
Abstrak : Kisah horor Desa Penari di Indonesia merupakan topik viral yang menjadi perbincangan warganet pada media sosial twitter. Berbagai tanggapan dan opini masyarakat muncul terkait kebenaran cerita pengalaman supranatural mahasiswa saat Kuliah Kerja Nyata di sebuah wilayah Jawa Timur Indonesia. Penelitian ini melakukan analisis sentimen dari komentarkomentar masyarakat pada media sosial Twitter terhadap topik viral tersebut menggunakan metode Lexicon Based. Klasifikasi sentimen dibagi menjadi 3 kelas yaitu positif, negatif dan netral. Tahap penelitian terdiri dari pengumpulan data, prapengolahan, pengolahan (analisis sentimen) dan visualisasi. Pengumpulan data menggunakan API Search Twitter dengan kata kunci Desa Penari sebanyak 1000 buah komentar (tweet) dalam bahasa Indonesia. Hasil penilaian leksikon dari 1000 data tweet diperoleh 33 tweet bernilai positif, 767 tweet bernilai netral dan 200 tweet negatif. Prosentase tweet berisi komentar positif sebesar $3.3 \%$, netral 76.7 $\%$ dan negatif sebesar $20 \%$.
\end{abstract}

Kata Kunci : Desa Penari, Analisis Sentimen, Lexicon Based, Twitter, WorldCloud

\section{PENDAHULUAN}

Perkembangan teknologi informasi dan internet memberi alternatif baru dalam berkomunikasi. Media sosial sebagai kumpulan perangkat lunak memungkinkan individu maupun komunitas untuk berkumpul, berbagi, berkomunikasi, berkolaborasi atau bermain. Ketersediaan berbagai layanan melalui media sosial yang dapat digunakan telah merubah cara berkomunikasi dalam masyarakat [1].
Hoot Suite We Are Social melakukan survei pada Januari 2019 menyatakan bahwa total pengguna aktif media sosial melalui internet di Indonesia mencapai 150 juta orang, artinya mencapai $56 \%$ dari total penduduk Indonesia. Penggunaan aplikasi sosial media di Indonesia [2] antara lain Youtube, Whatsapp, Facebook, Instagram, Line, Twitter, FB Messenger, BBM, Linkedin, Pinterest, Skype, Wechat, Snapchat, Path, Tumblr dan Reddit diilustrasikan pada Gambar 1. 


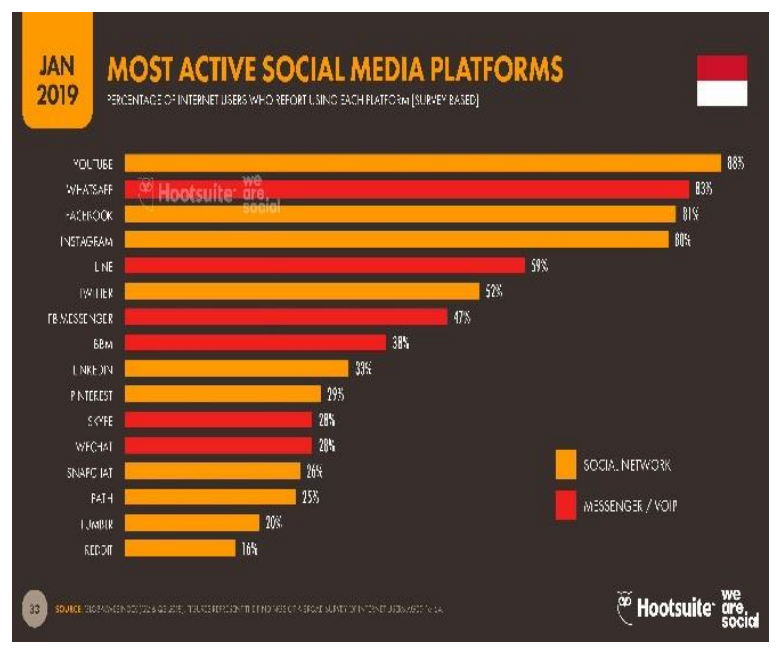

Gambar 1. Survey Penggunaan Sosial Media Di Indonesia Awal Tahun 2019 [2]

Masyarakat Indonesia menyukai kisah horor dan mistis baik dalam bentuk film, bendabenda, maupun kisah nyata. Perusahaan media intelligence Isentia menangkap perbincangan terkait keyword 'horor' dan 'mistis' di media sosial terhitung sejak 1 Agustus hingga 3 Oktober 2019 sebanyak 27.399 buzz. Warganet Indonesia memang memiliki kecenderungan tertarik terhadap kisah berbau horor, terbukti dari banyaknya topik viral terkait hal mistis terutama beberapa waktu belakangan ini. Terdapat empat topik utama yang paling viral berdasarkan urutan popularitasnya pada media sosial yaitu Boneka, KKN di Desa Penari, Orderan Mistis Ojol dan Film Danur [3] diilustrasikan pada Gambar 2.

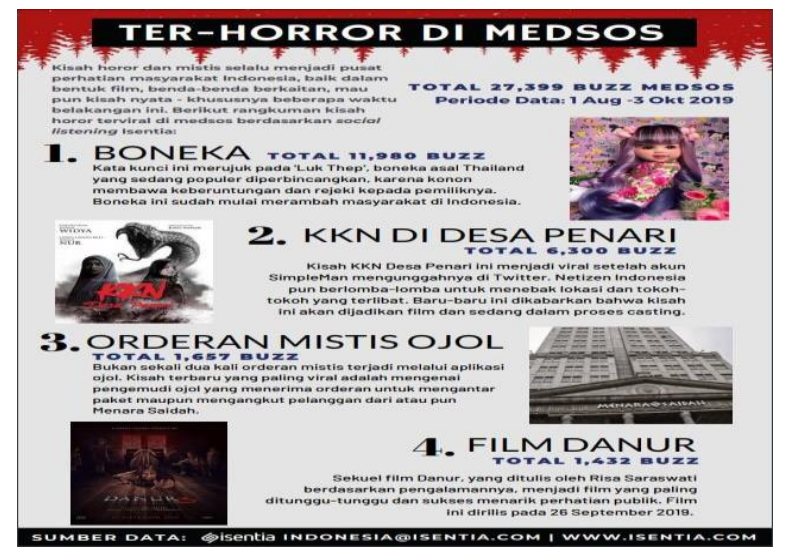

Gambar 2: Trend Topik Cerita Horor [3]
Analisis sentimen atau penambangan opini dapat didefinisikan sebagai tugas mendeteksi, mengekstraksi, dan mengklasifikasikan pendapat tentang sesuatu hal. Tugas ini merupakan jenis pemrosesan bahasa alami (NLP) untuk melacak mood publik untuk hukum, kebijakan, atau pemasaran tertentu, dll. Analisis sentimen melibatkan cara pengembangan untuk pengumpulan dan pemeriksaan komentar dan pendapat tentang undang-undang, kebijakan, dll., yang diposting di media sosial. Selain itu analisis sentimen berurusan dengan penambangan informasi terkait sentimen atau pendapat dari grup untuk topik tertentu. Sentimen analisis juga cukup populer pada berbagai bidang seperti politik yaitu untuk memperkirakan hasil pemilihan dari berbagai forum politik, bisnis yaitu untuk menganalisis sentimen online di media sosial untuk prediksi pasar saham dan pemasaran yaitu untuk memperkirakan penjualan produk spesifik [4].

Analisis sentimen adalah sebuah proses untuk menentukan sentimen atau opini dari seseorang yang diwujudkan dalam bentuk teks dan bisa dikategorikan sebagai sentimen positif, negatif atau netral. Pengguna internet banyak menuliskan pengalaman, opini dan segala hal yang menjadi perhatian mereka. Tulisan tentang apa yang mereka rasakan ini berupa perasaan positif, netral maupun negatif yang bisa diungkapkan dengan cara yang cukup kompleks [5] dalam [6]. Ide dasar dari investigasi sentimen adalah untuk mendeteksi polaritas teks dokumen atau kalimat pendek dan mengklasifikasikannya dalam premis ini. Polaritas sentimen dikategorikan sebagai 
"positif", "Negatif" atau "tidak memihak" (netral). Teknik yang ada untuk analisis sentimen termasuk pembelajaran mesin (diawasi dan tidak diawasi), dan pendekatan berbasis leksikal [7]. Berbagai penelitian terkait analisis sentimen berbagai topik di Indonesia telah banyak dilakukan antara lain dengan metode Nä̈ve Bayes [8], Support Vector Machine [9], DBF [10].

Penelitian ini akan membahas tentang analisis sentimen dari komentar masyarakat pada media sosial Twitter terhadap topik viral desa penari pada media sosial twitter dengan metode lexicon based. Tujuan penelitian ini adalah untuk mengelompokkan komentar masyarakat ke kategori sentimen positif, negatif dan netral berdasarkan lexicon.

\section{METODOLOGI PENELITIAN}

Pada penelitian ini dilakukan analisis sentimen kisah horor desa penari dengan metode Lexicon Based. Sentimen komentar masyarakat akan dikategorikan menjadi positif, negatif dan netral. Tahap penelitian terdiri dari pengumpulan data, pra pengolahan, pengolahan (analisis sentimen) dan visualisasi seperti ditunjukkan pada Gambar 4.

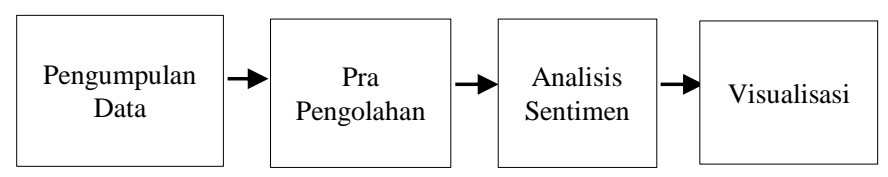

Gambar 4. Tahap Penelitian

\subsection{Pengumpulan Data}

Data yang digunakan adalah komentarkomentar masyarakat dari Twitter dengan kata kunci Desa Penari dan komentar dalam bahasa Indonesia sebanyak 1000 buah pada tanggal 13 November 2019. Proses diawali dengan membuat aplikasi Twitter, mengumpulkan data tweets dengan menggunakan akses pada Twitter Search API, mengubah kumpulan data (list tweets) menjadi data frame untuk membedakan konten dari atribut-atribut data yang diperoleh dalam bentuk tabel dan untuk proses selanjutnya hanya mengambil dan menggunakan isi konten dari atribut teks.

\subsection{Pra Pengolahan}

Pra pengolahan bertujuan untuk pengekstraksian dan pembersihan tweet yang akan digunakan pada tahap pengolahan (analisis sentimen /pengklasifikasian tweet). Proses terdiri antara lain: mengubah variabel teks menjadi karakter, mengubah huruf besar menjadi huruf kecil (case folding), menghapus tautan, menghapus mention (@), menghapus tanda baca, menghapus angka, menghapus stopword (kata "rt" dan "gt") dan menghapus whitespace (spasi yang berlebihan).

\subsection{Pengolahan (Analisis Sentimen)}

Setelah selesai melakukan tahap prapengolahan, dilanjutkan ke tahap pengolahan yaitu analisis sentimen untuk pengklasifikasian tweet. Metode Lexical based approach menggunakan sebuah kamus sebagai sumber bahasa atau leksikal. Dalam penelitian ini adalah opinion lexicon milik Liu [11] yang telah dimodifikasi dan ditranslate menjadi bahasa Indonesia oleh Devid Haryalesmana [12]. 
Tahap pengolahan terdiri dari 3 proses, yaitu mengimport kamus kata leksikon positif dan kamus kata leksikon negatif, memecah teks tweets menjadi bag of words (penggalan kata) yang bertujuan memudahkan pada saat penentuan skor positif, negatif dan netral serta menghitung skor sentimen positif, negatif dan netral dengan menggunakan metode Lexiconbased.

Skor dictionary based / lexicon based dihitung menggunakan rumus (1), (2) dan (3) :

if $\sum_{k}$ Score $(k)>0$ then positive

if $\sum_{k}$ score $(k)<0$ then negative

if $\sum_{k}$ score $(k)=0$ then Neutral

\subsection{Visualisasi}

Tahap akhir memvisualisasi hasil analisis sentimen dalam bentuk diagram histogram maupun wordcloud. Dengan menggunakan word cloud, gambaran frekuensi kata-kata dapat ditampilkan dalam bentuk yang menarik namun tetap informatif. Semakin sering satu kata digunakan, maka semakin besar pula ukuran kata tersebut ditampilkan dalam word cloud.

\section{HASIL DAN PEMBAHASAN}

\subsection{Hasil Pengumpulan Data}

Pengambilan data dengan API Search Twitter pada tanggal 13 November 2019 dengan kata kunci Desa Penari telah mengumpulkan sebanyak 1000 buah komentar (tweet) dalam bahasa Indonesia. Hasil pengambilan data yang diperoleh secara default berupa tweets berbentuk list ditunjukkan pada Gambar 5. Selanjutnya list tersebut perlu diubah menjadi data frame agar dapat diproses pada tahap analisis selanjutnya. Data frame berisi 16 variabel (atau bisa disebut sebagai field). Variabel-variabel tersebut adalah: 1). text, berisi teks tweets. 2). favorited, berisi nilai Boolean mengenai apakah tweets difavoritekan pengguna/pengguna lain. 3). favoriteCount, berisi jumlah kali tweets difavoritekan. 4). replyToSN, berisi nama akun ke mana tweets dibalaskan. 5). created, berisi tanggal dan jam tweets dibuat. 6). truncated, berisi nilai Boolean apakah tweets terpotong. 7). replyToSID, berisi ID tweets balasan. 8). id, berisi ID tweets. 9). replyToUID, berisi ID pengguna ke mana tweets dibalaskan. 10). statusSource, berisi sumber user agent dari tweets. 11). screenName, berisi nama akun pembuat tweets. 12). retweetCount, berisi jumlah kali tweets di-retweet. 13). isRetweet, berisi nilai Boolean apakah suatu tweets merupakan sebuah retweet. 14). retweeted, berisi nilai Boolean apakah suatu tweets di-retweet. 15). longitude, berisi ordinat garis bujur tempat tweets dibuat. 16). latitude, berisi ordinat garis lintang tempat tweets dibuat. Hasil perubahan list data tweet yang disimpan menjadi data frame ditunjukkan pada Gambar 6. Kemudian melakukan pengambilan hanya konten teksnya saja yaitu pada atribut text. Hasil pengumpulan hanya konten teks ditunjukkan pada Gambar 7. 


\begin{tabular}{|c|c|c|}
\hline \multirow{2}{*}{ analisis } & list [1000] & List of length 1000 \\
\hline & S4 [1] (twitteR::status) & \\
\hline .> favoriteCount & double [1] & 0 \\
\hline.$>$ id & character [1] & '1195533100337381376' \\
\hline .> isRetweet & logical & TRUE \\
\hline .->latitude & character $[0]$ & \\
\hline .> replyToSN & character $[0]$ & \\
\hline .> replyToUID & character $[0]$ & \\
\hline$\therefore$ retweetCount & double [1] & 3550 \\
\hline .-> retweeted & logical & FALSE \\
\hline ->screenName & character [1] & 'FebrianaYH' \\
\hline .> statusSource & character [1] & " $<$ a href="http://twitter.com/download/iphone" rel="nofollow" $>$ Twitter for iPhone $<$... \\
\hline ( ) self & S4 [1] (twitteR::status) & \\
\hline created & double (S3: POSIXct, POSIXt) & 2019-11-16 02:44:37 \\
\hline
\end{tabular}

\section{Gambar 5. Hasil Pengambilan Data Dari API Search Tweeter}

\begin{tabular}{|c|c|c|c|c|c|c|c|c|c|}
\hline 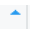 & text & favorited & favoriteCount & replyToSN & created & truncated & replyToSID & id & replyTo \\
\hline 1 & RT @Evan_sadis: Ini kisah KKN Desa Penari akan cek di y... & FALSE & 0 & NA & $2019-11-1602: 44: 37$ & FALSE & NA & 1195533100337381376 & \\
\hline 2 & RT @levannaayu: Postingan ini hilang, sama kayak thre... & FALSE & 0 & NA & 2019-11-16 02:42:31 & FALSE & NA & 1195532569632108544 & NA \\
\hline 3 & KKN desa penari $\langle\mathrm{U}+0001 \mathrm{~F} 9 \mathrm{DA}\rangle\langle\mathrm{U}+200 \mathrm{D}\rangle\langle\mathrm{U}+2640\rangle \ldots$ & FALSE & 0 & NA & 2019-11-16 02:36:07 & FALSE & NA & 1195530962349838336 & NA \\
\hline 4 & https://t.co/dVOjq19Ftt Gunung Lawu & FALSE & 0 & NA & 2019-11-16 02:27:31 & FALSE & NA & 1195528797405081601 & NA \\
\hline 5 & @iassssssssss @vulpeculai Ini ayamnya macam bima kete... & FALSE & 0 & iasssssssssss & 2019-11-16 02:00:54 & FALSE & 1195237660836556801 & 1195522099458134016 & $104 i$ \\
\hline 6 & RT @nurulthfh: MET PAGI CANTIQUE @malikatazkia YAN... & FALSE & 0 & NA & $2019-11-16$ 01:18:08 & FALSE & NA & 1195511335926161411 & NA \\
\hline 7 & MET PAGI CANTIQUE @malikatazkia YANG KUAT DAN MEN... & FALSE & 1 & NA & 2019-11-16 01:16:20 & FALSE & NA & 1195510882366672901 & NA \\
\hline 8 & RT @fianahsrnd: asyikkk bener deh jogetnya $<U+0001 F . .$. & FALSE & 0 & NA & 2019-11-16 01:10:45 & FALSE & NA & 1195509477362896897 & NA \\
\hline 9 & @SimpleM81378523 @auraaapi @bacahorror Kkn desa ... & FALSE & 0 & SimpleM81378523 & 2019-11-16 01:10:28 & FALSE & 1180793234793959425 & 1195509405065740288 & 1095 \\
\hline 10 & @juhyuqn kerasukan desa penari & FALSE & 0 & juhyuqn & 2019-11-16 00:50:26 & FALSE & 1195502572905189376 & 1195504363612987392 & 1814 \\
\hline 11 & RT @anakorang: @Askmenfess Jan: 80jt Feb: unboxing s... & FALSE & 0 & NA & 2019-11-16 00:43:10 & FALSE & NA & 1195502533692669953 & NA \\
\hline 12 & RT @Juyeonescent: Soonyoung sepulangnya dari KKN di... & FALSE & 0 & NA & $2019-11-1600: 31: 48$ & FALSE & NA & 1195499674733436928 & NA \\
\hline 13 & https://t.co/dVOjq19Ftt Kokos Jiang: Kokos Leo Lim & FALSE & 0 & NA & 2019-11-15 20:28:01 & FALSE & NA & 1195438325739294720 & NA \\
\hline 14 & @kalonggg Pless deh ea, kamutu jan riyak taw gak, me... & FALSE & 0 & kalonggg & 2019-11-15 20:19:53 & TRUE & 1195434802280747008 & 1195436276645687296 & $112 \Xi$ \\
\hline 15 & RT @korantempo: Wisata kuliner kelapa kopyor ini seda... & FALSE & 0 & NA & 2019-11-15 20:07:00 & FALSE & NA & 1195433037829492737 & NA \\
\hline 16 & RT @korantempo: Nama Desa Penari tiba-tiba menjadi p... & FALSE & 0 & NA & 2019-11-15 19:22:00 & FALSE & NA & 1195421712550187008 & NA \\
\hline 17 & @kdryvk Dia ini sto yg kkn desa penari :( & FALSE & 0 & kdryuk & 2019-11-15 18:55:20 & FALSE & 1195414882742489088 & 1195415000770203648 & $112=$ \\
\hline 18 & @Askmenfess Gambaran widya lagi nari di kisah kkn de... & FALSE & 0 & Askmenfess & 2019-11-15 18:51:58 & FALSE & 1195413892547039232 & 1195414153831206912 & 8104 \\
\hline 19 & @Askmenfess penari desa kkn & FALSE & 0 & Askmenfess & 2019-11-15 18:51:44 & FALSE & 1195413892547039232 & 1195414092443344896 & 8104 \\
\hline 20 & RT @ debrisumule: Anna juga gamau kalah donggg.. nar... & FALSE & 0 & NA & 2019-11-15 18:17:49 & FALSE & NA & 1195405557517041664 & \\
\hline
\end{tabular}

\section{Gambar 6. Hasil List Tweet Yang Telah Diubah Menjadi Data Frame}

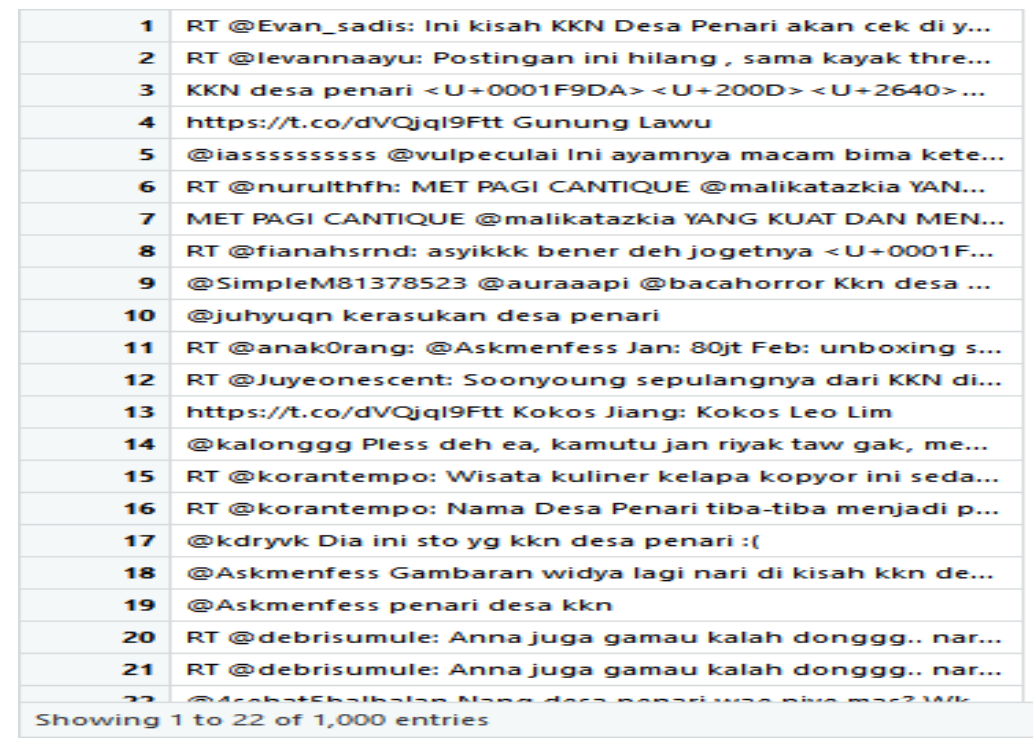

Gambar 7. Hasil Pengambilan Konten Teks Dari Atribut Text Pada Data Frame 


\subsection{Hasil Pra Pengolahan}

Pra pengolahan dilakukan terhadap konten teks dari atribut teks pada data frame yaitu mengubah variabel teks menjadi karakter, mengubah huruf besar menjadi huruf kecil (case folding), menghapus tautan, menghapus mention (@), menghapus tanda baca, menghapus angka, menghapus stopword (kata "rt" dan "gt") dan menghapus whitespace (spasi yang berlebihan). Perubahan isi konten teks melalui proses pra pengolahan secara berkelanjutan ditunjukkan pada Tabel 1 sampai Tabel 4. Hasil akhir setelah prapengolahan ditunjukkan pada Gambar 8.

\section{Tabel 1. Proses case folding}

\begin{tabular}{|c|c|}
\hline No & Sebelum \\
\hline 1 & $\begin{array}{l}\text { RT @Evan_sadis: Ini rt @evan_sadis: ini } \\
\text { kisah KKN Desa Penari kisah kkn desa penari } \\
\text { akan cek di youtube akan cek di youtube } \\
\text { Sisitv. \#layangputus sisitv. \#layangputus } \\
\text { Inalilahiwainailaihirojiu inalilahiwainailaihiroji } \\
n \text { \#kisahanakkampung un \#kisahanakkampung } \\
\text { https://... https:// }\end{array}$ \\
\hline 2 & $\begin{array}{l}\text { RT @levannaayu: rt @levannaayu: } \\
\text { Postingan ini hilang, postingan ini hilang, } \\
\text { sama kayak thread kkn sama kayak thread kkn } \\
\text { desa penari waktu itu. desa penari waktu itu. } \\
\text { \#bacahoror } \\
\text { \#bacahoror } \\
\text { https://t.co/LyladcDBKy https://t.co/lyladcdbky }\end{array}$ \\
\hline 3 & $\begin{array}{l}\text { @SimpleM81378523 @ simplem81378523 } \\
\text { @auraaapi } \\
\text { @ @acahorror Kkn desa @ bacahorror kkn desa } \\
\text { penari saja ku belum penari saja ku belum } \\
\text { baca:( } \\
\text { baca }:(\end{array}$ \\
\hline 4 & 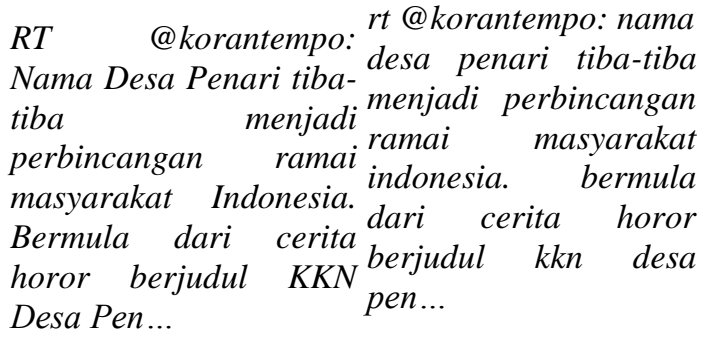 \\
\hline
\end{tabular}

\section{Tabel 2. Proses Penghapusan Tautan}

\begin{tabular}{|c|c|}
\hline No & Sebelum \\
\hline 1 & 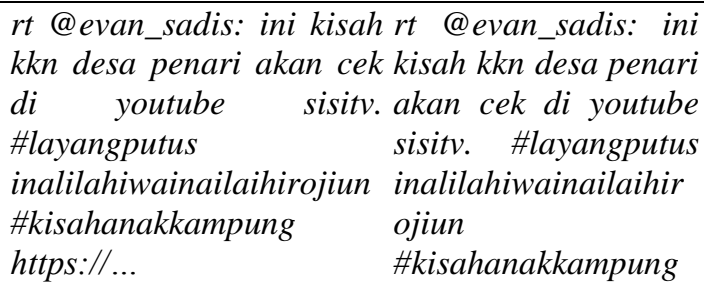 \\
\hline 2 & $\begin{array}{l}\text { rt @levannaayu: rt } \text { @levannaayu: } \\
\text { postingan ini hilang, postingan ini hilang, } \\
\text { sama kayak thread kkn sama kayak thread } \\
\text { desa penari waktu itu. kkn desa penari } \\
\text { \#bacahoror @bacahorror waktu } \\
\text { https://t.co/lyladcdbky \#bacahoror } \\
\begin{array}{c}\text { @bacahorror } \\
\end{array}\end{array}$ \\
\hline 3 & $\begin{array}{l}\text { @ simplem81378523 @ simplem81378523 } \\
\text { @auraaapi @bacahorror @auraaapi } \\
\text { kkn desa penari sajaku @bacahorror kkn } \\
\text { belum baca:( } \\
\begin{array}{l}\text { desa penari saja ku } \\
\text { belum baca :( }\end{array}\end{array}$ \\
\hline 4 & $\begin{array}{l}r t \text { @korantempo: nama rt @korantempo: } \\
\text { desa penari tiba-tiba nama desa penari } \\
\text { menjadi perbincangan tiba-tiba menjadi } \\
\text { ramai masyarakat perbincangan ramai } \\
\text { indonesia. bermula dari masyarakat } \\
\text { cerita horor berjudul kkn indonesia. bermula } \\
\text { desa pen... } \\
\text { dari cerita horor } \\
\text { berjudul kkn desa } \\
\text { pen... }\end{array}$ \\
\hline
\end{tabular}

\section{Tabel 3. Proses Penghapusan Mention}

\begin{tabular}{|c|c|}
\hline No & $\begin{array}{rr}\text { Sebelum } & \text { Sesudah } \\
\end{array}$ \\
\hline 1 & $\begin{array}{l}r t \text { @evan_sadis: ini rt: ini kisah kkn desa } \\
\text { kisah kkn desa penari penari akan cek di } \\
\text { akan cek di youtube youtube } \\
\text { sisitv. \#layangputus \#layangputus } \\
\text { inalilahiwainailaihiroji inalilahiwainailaihirojiu } \\
\text { un \#kisahanakkampung n \#kisahanakkampung }\end{array}$ \\
\hline & $\begin{array}{l}\text { rt @levannaayu: rt: postingan ini hilang, } \\
\text { postingan ini hilang, sama kayak thread kkn } \\
\text { sama kayak thread kkn desa penari waktu itu. } \\
\text { desa penari waktu itu. \#bacahoror } \\
\text { \#bacahoror } \\
\text { @bacahorror }\end{array}$ \\
\hline & $\begin{array}{l}\text { simplem81378523 kkn desa penari saja ku } \\
\text { auraaapi belum baca:( } \\
\text { bacahorror kkn desa } \\
\text { nari saja ku belum } \\
\text { ca :( }\end{array}$ \\
\hline & $\begin{array}{l}r t @ \text { korantempo: nama rt: nama desa penari } \\
\text { desa penari tiba-tiba tiba-tiba menjadi } \\
\text { menjadi perbincangan perbincangan ramai } \\
\text { ramai masyarakat masyarakat indonesia. } \\
\text { indonesia. bermula dari bermula dari cerita } \\
\text { cerita horor berjudul horor berjudul kkn desa } \\
k \text { kn desa pen... pen... }\end{array}$ \\
\hline
\end{tabular}


Tabel 4. Proses Penghapusan Tanda Baca

\begin{tabular}{|c|c|c|}
\hline No & Sebelum & Sesudah \\
\hline 1 & $\begin{array}{l}\text { rt: ini kisah kkn desa } \\
\text { penari akan cek di } \\
\text { youtube sisitv. } \\
\text { \#layangputus } \\
\text { inalilahiwainailaihiroj } \\
\text { iun } \\
\text { \#kisahanakkampung }\end{array}$ & $\begin{array}{l}\text { rt ini kisah kkn desa } \\
\text { penari akan cek di } \\
\text { youtube } \\
\text { layangputus sisitv } \\
\text { inalilahiwainailaihiroji } \\
\text { un kisahanakkampung }\end{array}$ \\
\hline 2 & $\begin{array}{l}\text { rt: postingan ini } \\
\text { hilang, sama kayak } \\
\text { thread kkn desa penart } \\
\text { waktu itu. \#bacahoror }\end{array}$ & $\begin{array}{l}\text { rt postingan ini hilang } \\
\text { sama kayak thread kkn } \\
\text { desa penari waktu itu } \\
\text { bacahoror }\end{array}$ \\
\hline 3 & $\begin{array}{l}\text { kkn desa penari saja } \\
\text { ku belum baca :( }\end{array}$ & $\begin{array}{l}\text { kkn desa penari saja ku } \\
\text { belum baca }\end{array}$ \\
\hline 4 & $\begin{array}{l}\text { rt: nama desa penari } \\
\text { tiba-tiba menjadi } \\
\text { perbincangan ramai } \\
\text { masyarakat indonesia. } \\
\text { bermula dari cerita } \\
\text { horor berjudul kkn } \\
\text { desa pen... }\end{array}$ & $\begin{array}{l}\text { rt nama desa penari } \\
\text { tiba-tiba menjadi } \\
\text { perbincangan ramai } \\
\text { masyarakat indonesia. } \\
\text { bermula dari cerita } \\
\text { horor berjudul kkn desa } \\
\text { pen... }\end{array}$ \\
\hline
\end{tabular}

Selanjutnya adalah proses penghapusan angka, penghapusan stopword [12] dan menghapus whitespace (spasi yang berlebihan).

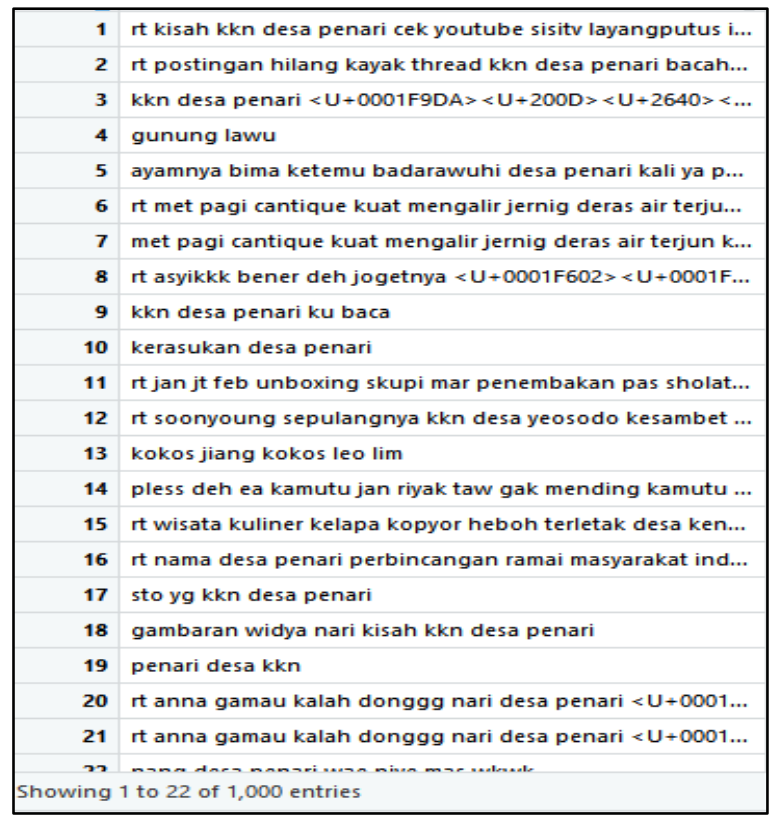

Gambar 8. Hasil Teks Setelah Pra pengolahan

\subsection{Hasil Pengolahan}

Tahap pengolahan terdiri dari 3 proses, yaitu mengimport kamus kata dalam bahasa Indonesia yang dipisah menjadi leksikon positif dan kamus kata leksikon negatif, memecah teks tweets menjadi bag of words (penggalan kata) dan menghitung skor sentimen positif, negatif dan netral menggunakan metode Lexicon-based.

Leksikon positif, menyaring kata bermakna positif dan berubah menjadi array dengan nama positive.txt. ditunjukkan pada Gambar 9.

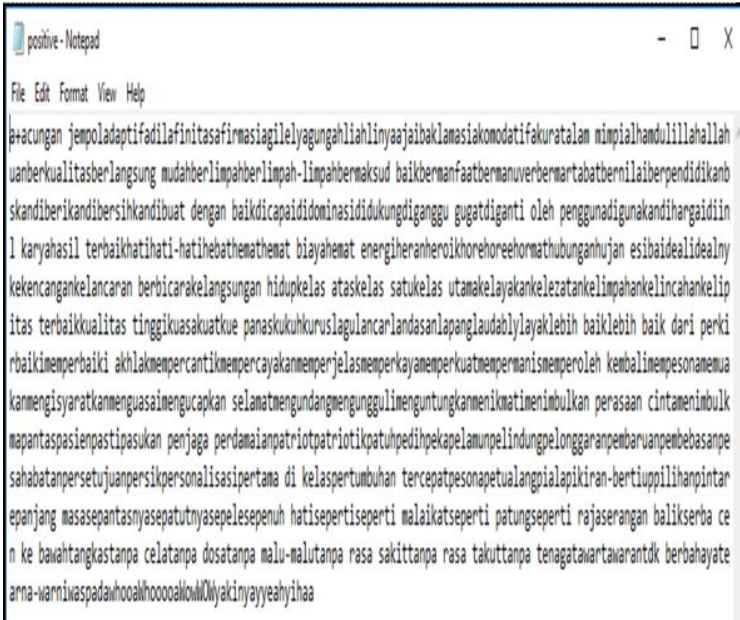

Gambar 9. Kamus Kata Positif

Leksikon negatif, menyaring kata bermakna negatif dan berubah menjadi array bernama negative.txt. ditunjukkan pada Gambar 10.
File bat foumet Vian Hep

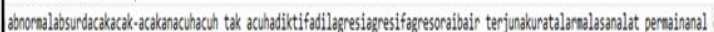

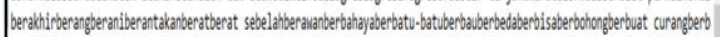

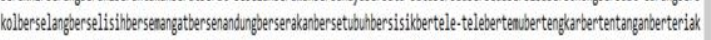
dengan penuh ketakutandengan rass curigadengan rasa hinadengan reneh-tenendengan sedilidengan segandengan sengittengan sia-s

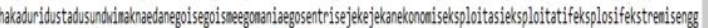

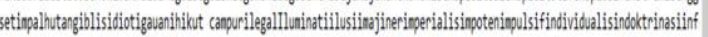

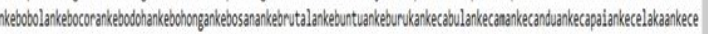

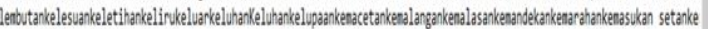

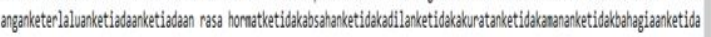

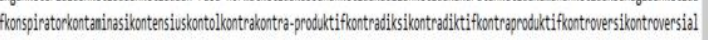

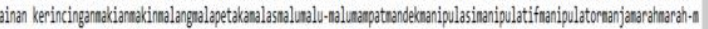

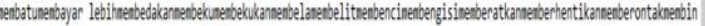

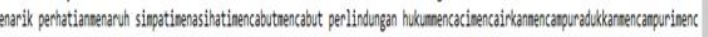

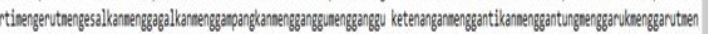

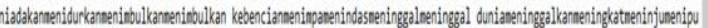

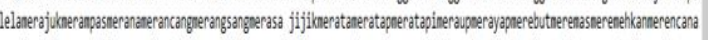

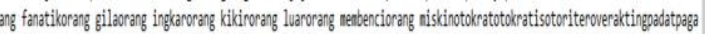

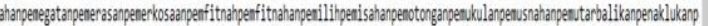

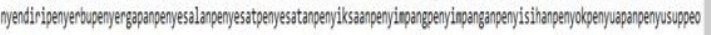

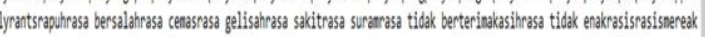

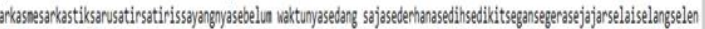

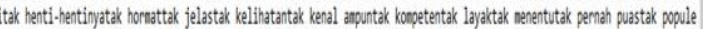

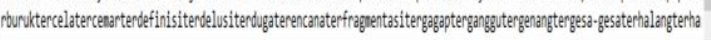

\section{Gambar 10. Kamus Kata Negatif}


Proses memecah teks tweets menjadi bags of words agar tweets menjadi penggalan kata ditunjukkan pada Gambar 11.

\begin{tabular}{|c|c|c|}
\hline Name & Type & 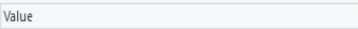 \\
\hline O bo_teks_analisis & list [1000] & List of length 1000 \\
\hline$[[1]]$ & character [13] & 'tt' 'kisah' 'kkn' 'desa' 'penari' 'cek' '... \\
\hline [[2]] & character [10] & 'tt' postingan' 'hilang' 'kayak' 'thread' 'kkn'... \\
\hline [[3]]] & character $[10]$ & 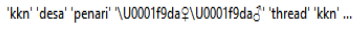 \\
\hline [[4]]] & character [3] & "'gunung' lawu' \\
\hline [[5]] & character [16] & " 'ayamnya' 'bima' 'ketemu' 'badarawuhi' 'desa' ... \\
\hline [[6]] & character [20] & 'rt' 'met' 'pagi' 'cantique' 'kuat ' 'mengalir' ... \\
\hline$[[]]$ & character [17] & 'met' 'pagi' 'cantique' 'kuatt 'mengalir' 'jenig' ... \\
\hline$[[8]]$ & character [18] & 'rt' 'asyikkk' 'bener' 'deh' 'jogetnya' ' U000011602Z U000019923' ... \\
\hline [[9]] & character $[7]$ & " 'kkn' 'desa' 'penari 'ku' 'baca' '... \\
\hline [[100]] & character $[4]$ & " 'kerasukan' 'desa' 'penari' \\
\hline [[11]] & character [17] & 'It' 'jan' 'jt' 'feb' ' unboxing' 'skupi' '... \\
\hline [[12]] & character [11] & 'rt' 'soonyoung' 'sepulangnya' 'kkn' 'desa' 'yeosodo'.... \\
\hline [[131]] & character [6] & " 'kokos' Jiang' 'kokos' 'leo' 'lim' \\
\hline [[144]] & character [20] & " 'pless' 'deh' 'ea' 'kamutu' 'jan' .... \\
\hline [[15]] & character [13] & 'tr' 'wistat 'kuliner' 'kelapa' 'kopyor' 'heboh' ...' \\
\hline [[16]] & character [14] & 'tr' 'nama' ' desa' 'penari' 'perbincangan' 'ramai' ... \\
\hline$[[17]]$ & character $[7]$ & " 'sto' 'yg' 'kkn' 'desa' 'penari' ... \\
\hline [[18]] & character [8] & " 'gambaran' 'widya' 'nari' 'kisah' 'kkn' ... \\
\hline [[19]] & character $[4]$ & " 'penari' 'desa' 'kn' \\
\hline IIDNII & chararter [151 & 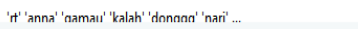 \\
\hline
\end{tabular}

Gambar 11. Hasil Pemecahan Teks Menjadi Bag of Word (Penggalan Kata)

Tahap selanjutnya penghitungan skor untuk menggolongkan tweets positif, negatif dan netral. Tweet yang memiliki jumlah skor positif lebih besar dari skor negatif maka digolongkan pada sentimen positif, begitu sebaliknya. Jika tweet tersebut memiliki skor positif dan negatif yang sama, maka digolongkan dalam sentimen netral. Hasil analisis ditunjukkan pada Gambar 12.

\begin{tabular}{|c|c|c|}
\hline teks_analisis_22 & list [1002] & List of length 1002 \\
\hline [[1]]] & integer [1] & 0 \\
\hline [[2]] & integer [1] & 0 \\
\hline [[3]] & integer [1] & 0 \\
\hline [[4]]] & integer [1] & 0 \\
\hline [[5]] & integer [1] & -1 \\
\hline [[6]] & integer [1] & -2 \\
\hline [[7]] & integer [1] & -2 \\
\hline [[8]] & integer [1] & -1 \\
\hline$[[9]]$ & integer [1] & -1 \\
\hline [[10]] & integer [1] & 0 \\
\hline [[11]] & integer [1] & -1 \\
\hline [[12]] & integer [1] & 0 \\
\hline [[13]] & integer [1] & 0 \\
\hline [[14]] & integer [1] & -1 \\
\hline [[15]] & integer [1] & 0 \\
\hline [[16]] & integer [1] & -2 \\
\hline [[17]] & integer [1] & 0 \\
\hline [[18]] & integer [1] & 0 \\
\hline [[19]] & integer [1] & 0 \\
\hline [[20]] & integer [1] & 0 \\
\hline
\end{tabular}

Gambar 12. Hasil Skor Analis Sentimen Dengan Lexicon Based

\subsection{Hasil Visualisasi}

Tahap terakhir dalam penelitian ini adalah memvisualisasi hasil klasifikasi algoritma Lexicon Based untuk proporsi bagian - bagian tweet yaitu positif, negative, dan netral. Hasil Visualisasi Dalam Histogram disajikan pada Gambar 13 dan dan WordCloud pada Gambar 14.

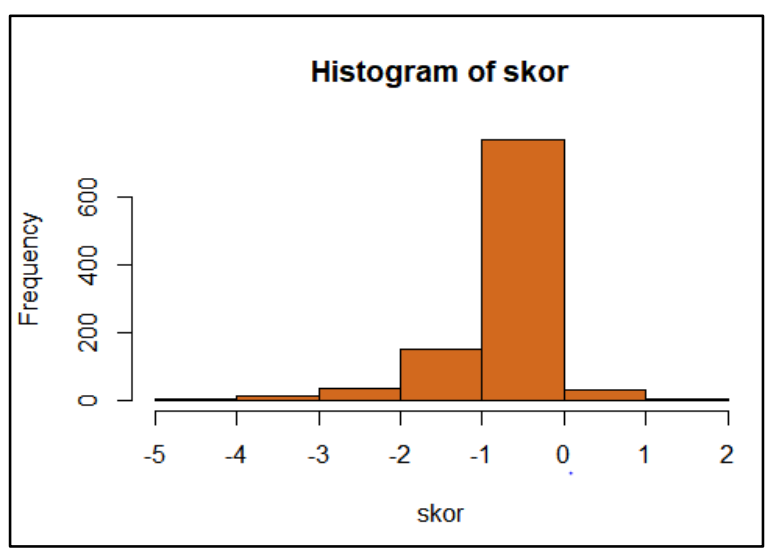

\section{Gambar 13. Hasil Visualisasi Dalam Histogram}

Visualisasi dalam wordcloud yang menunjukkan kata-kata yang sering muncul dalam keseluruhan tweet Desa Penari ditunjukkan pada Gambar 14.

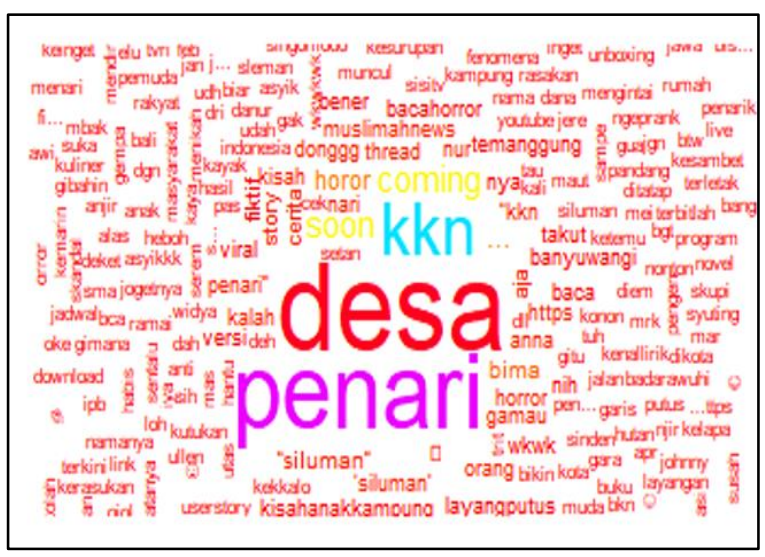

Gambar 14. Visualisasi Dalam WordCloud

Tabel 5. Penilaian Dengan Lexicon Based

\begin{tabular}{ccc}
\hline Kategori & Jumlah & Prosentase \\
\hline Positif & 33 & $3.3 \%$ \\
Netral & 767 & $76.7 \%$ \\
Negatif & 200 & $20 \%$ \\
\hline
\end{tabular}


Tabel 5 menunjukkan penilaian leksikon dari 1000 data tweet diperoleh 33 tweet bernilai positif, 767 tweet bernilai netral dan 200 tweet negatif. Prosentase tweet berisi komentar positif sebesar $3.3 \%$, netral $76.7 \%$ dan negatif sebesar $20 \%$.

\section{KESIMPULAN}

Paper ini melakukan analisis sentimen topik viral desa penari pada media sosial twitter dengan metode lexicon based. Berdasar 1000 data tweet yang dianalisis diperoleh hasil 33 tweet positif (3.3\%), 767 tweet netral $(76.7 \%)$ dan 200 tweet negatif (20\%). Dapat disimpulkan analisis sentimen komentar masyarakat terhadap cerita ini kebanyakan adalah bersifat netral.

\section{DAFTAR PUSTAKA}

[1] A. Clara Sari, R. Hartina, R. Awalia, H. Irianti, N. Ainun, "Komunikasi dan Media Sosial, Research Gate, 2019.

[2] Websindo, "Indonesia Digital 2019: Media Sosial", Websindo. [Online]. Available: https://websindo.com/indonesiadigital-2019-media-sosial/ [Accessed: 17Oct-2019).

[3] DetikInet, "Kisah Horor yang Viral di Medsos selain KKN di Desa Penari", DetikInet.

[Online].

https://inet.detik.com/cyberlife/d-

4733844/kisah-horor-yang-viral-di-medsosselain-kkn-di-desa-penari. [Accessed: 10Oct-2019).

[4] B. Saberi and S. Saad, "Sentiment Analysis or Opinion Mining: A Review", Ijaseit Vol.7 No. 5 pp 1660-1666, 2017.

[5] Troussas, C. et al, "Sentiment analysis of Facebook statuses using Naive Bayes classifier for language learning", In IISA 2013. IEEE, pp. 1-6. Available at: http://ieeexplore.ieee.org/lpdocs/epic03/wra pp er.htm?arnumber=6623713 [Accessed May 7, 2015]

[6] N.M.S. Hadna, P.I. Santosa, W.W. Winarno, "Studi Literatur Tentang Perbandingan Metode Untuk Proses Analisis Sentimen Di Twitter", Seminar Nasional Teknologi Informasi dan Komunikasi 2016 (SENTIKA 2016), 2016, pp 57-64.

[7] A. Alsaeedi, M.Z. Khan, "A Study on Sentiment Analysis Techniques of Twitter Data", International Journal of Advanced Computer Science and Applications, Vol. 10, No. 2, pp 361-374, 2019.

[8] Billy Gunawan, Helen Sastypratiwi, Enda Esyudha Pratama, "Sistem Analisis Sentimen pada Ulasan Produk Menggunakan Metode Naive Bayes", Jurnal Edukasi dan Penelitian Informatika, Vol 4, No 2, pp 113-118, 2018

[9] W. Athira Luqyana, I. Cholissodin, R.Setya Perdana, "Analisis Sentimen Cyberbullying pada Komentar Instagram dengan Metode Klasifikasi Support Vector Machine", Jurnal Pengembangan Teknologi Informasi dan Ilmu Komputer Vol. 2, No. 11, November 2018, pp. 4704-4713, 2018

[10] I. Zulfa, E Winarko, "Sentimen Analisis Tweet Berbahasa Indonesia dengan Deep Belief Network, IJCCS, Vol.11, No.2, July 2017, pp. 187-198, 2017

[11] Liu, Bing, $\mathrm{Hu}$, Minqing, and Cheng, Junsheng (2005). "Opinion Observer: Analyzing and Comparing Opinions on the Web." Proceedings of the 14th International World Wide Web Conference (WWW2005), May 10-14, Chiba, Japan.

[12] Github. Devid Haryalesmana. ID-Opinion Words. 27 Juli 2019 [Online]. Tersedia : https://github.com/masdevid/ID-

OpinionWords. [Diakses : 27 Juli 2019]. 